\title{
Sequential Organization of Indonesian Stand-Up Comedy Performance
}

\author{
Dwi Indarti \\ Universitas Bina Sarana Informatika \\ Email: dwi.diw@bsi.ac.id

\begin{tabular}{ccc}
\hline Diterima & Direvisi & Disetujui \\
$18-06-2020$ & $07-07-2020$ & $31-08-2020$ \\
\hline
\end{tabular}

\begin{abstract}
This paper aims to analyze the sequential organization of three Indonesian Comics who performed in Grand Final SUCI season five. Using the serial sequential organization proposed by (Scarpetta, F. \& Spagnolli, 2009) as the theoretical framework, this study outlines the narrative of the stand-up comedy's texts and seeks whether there is a difference between the three finalists of SUCI 5 in delivering their narratives. The results of the study show that the three finalists of SUCI 5 follow the sequential step proposed by (Scarpetta, F. \& Spagnolli, 2009)The difference among them can be seen in terms of expanding successful joke. Rahmet and Rigen are more expand their jokes rather than Indra.
\end{abstract}

Keywords: Sequential Organization; stand-up comedy; discourse analysis.

Abstrak - Penelitian ini bertujuan untuk menganalisa urutan-urutan narasi dari tiga komika yang menjadi finalis pada SUCI musim kelima. Dengan menggunalan teori urutan narasi yang digagas oleh (Scarpetta, F. \& Spagnolli, 2009) sebagai kerangka teori, penelitian ini menjabarkan garis besar narasi dari teks stand-up comedy yang ditampilkan oleh ketiga finalis SUCI musim kelima dan mencari apakah ada perbedaan pola diantara ketiga finalis tersebut dalam menyampaikan narasi stand-up comedy mereka pada acara final SUCI musim kelima. Hasil penelitian ini menunjukkan bahwa ketiga finalis SUCI musim kelima mengikuti Langkah urutan narasi yang digagas oleh (Scarpetta, F. \& Spagnolli, 2009). Perbedaan diantara ketiganya dapat dilihat dari segi pengembangan materi humor. Rahmet dan Rigen lebih mengembangkan humor dibandingkan Indra.

Kata kunci: Urutan Narasi; stand-up comedy; analisa teks.

\section{INTRODUCTION}

Humor or comedy is a central aspect of daily conversations from human's speech and behavior that become the inspirations for laughing (Schwarz (2010) as cited in (Filani, 2015). Mintz (1985) as cited in (Scarpetta, F. \& Spagnolli, 2009) identifies stand-up comedy as "an encounter between a single, standing performer behaving comically and or saying funny things directly to an audience, unsupported by very much in the way of costume, prop, setting, or dramatic vehicle" (p.71). Moreover, stand-up comedy is an art form, and therefore has aesthetic and ethical dimensions; comedy is ceremonial and has its rules and rituals; comedy is oriented to public occasions and can be celebratory (Morris, 2011). Meanwhile, (Glick, 2007) defined that stand-up comedy routines are at first glance quite simple performative events. Typically, a lone comedian stands on a stage with a microphone and talks to an audience that has paid to be present. (Glick, 2007) stated that the official purpose of the performance is for the comedian to make the audience laugh and thereby entertain them. The materials of stand-up comedy are about something regarding human's behavior that is delivered in humorous way. Comedy or humor has been known and responded through laugh before it is packed in entertainment show. According to (Komedibadi, 2017), around 487 B.C, it had been found that ancient Greek people flocked to the theater to watch comedy. It means that stand-up comedy has been known for centuries. (Glick, 2007) argued that the topics of stand-up comedy are usually about ideology, politic, ethnic and other popular issues, and since the limitation of properties, stand-up comedians use some performative techniques to engage the audience and elicit laugther. (Hughes, 2016) pointed out that the success of live comedy depends on a performer's ability to work an audience. Ethnographic studies suggest that this involves the coordinated use of subtle social signals such as body orientation, gesture, gaze by both performers and audience members. Meanwhile (Smith, 2018) argued that a sociological theory of humor needs to be sensitive to the type of sociality, personhood and collective representations which drive contemporary stand-up comedy. It outlines stand-up comedy as the art of inter-personal relations where self-other, stranger 
sociality is built, improvised and performatively situated.

Humour and comedy have been investigated in the field of linguistics. (Rutter, 2001) wrote a paper to look stand-up comedy performances and the ways in which successful comedians use rhetorical techniques which are of specific importance in stand-up comedy: $R e$ Incorporations, Alliteration and Assonance, Character Fooling and Intonation. Furthermore, (Rutter, 2001) explained that the role these techniques play in differentiating between jokes as text and joking as text and joking as a performative interaction is explored. This paper shows that the use of these rhetorical techniques is strongly linked to audience laughter for which previous approaches to joking provide only limited explanations. It argues that comedians use these techniques to signpost punchlines as points at which laughter is a preferred response from an audience. (Filani, 2015) conducted a research in term of discourse types in stand-up comedy performances. He used an example of Nigerian stand-up comedy to postulate two contexts in stand-up joking stories: context of the joke and context in the joke. His research revealed that stand-up comedians perform discourse types, which are specific communicative acts in the context of the joke, such as greeting/salutation, reporting and informing, which bifurcates into selfpraising and self-denigrating (p. 41). Meanwhile, (Glick, 2007) wrote a paper about performative techniques of stand-up comedy. He exercised the textuality of temporalization and explored the verbal art of stand-up comedy. Yus (2004) as cited in (Filani, 2015) took a relevance theoretic perspective to investigate the pragmatic strategies stand-up comedians employ in their routines and how such strategies entail the entertainment. (Rullyanti, M, 2019) conducted a study focused on the stand-up comedy script brought by Chris Rock who is known for his insulting comedian, satire and surreal language style in his jokes. Using the standup comedy script tittle "Kill the messenger", the study found ten rhetorical language styles and 17 figurative language, where hyperbola style and epithet figurative language are dominantly used in his joke. The study also revealed that the reason is because Chris Rock tried to persuade the white skin American to be humble to black skin American and they much respect to each other. (Gurillo, L. R, Linares, 2019) explored subversive humor in Spanish stand-up comedy by analyzing the work of two well-known Spanish female comedians. Using a corpus of those comedians' performances, comprising a total of 25 monologues, the analysis focused on subversive humorous sequences, which has shown that only $22,38 \%$ of the sequences from Eva Hache's comic monologues are mainly built around subverting the status quo, whereas Patricia Sornosa challenges the heteronormative discourse in most of her sequences $(87,93 \%)$. The study also examined the main linguistic techniques used when challenging the heteronormative standards, namely the topics, targets, discourse strategies and linguistic cues used to generate a subversive effect. The findings showed that both comics females used subversive humor but in different ways because of contextual constraints. Meanwhile, (Gurillo, L. R, Linares, 2019) conducted a research to examine Eva Hache's humorous gender-related monologues. The paper offered a case study in three different ways. First, an analysis of different humorous sequences makes it possible to distinguish a representation of both feminine and masculine identities, as well as a confrontation between the two genders. Second, a polyphonic study of men as speakers (locutors) and utterers served to differentiate certain features of their identity from a discursive perspective. Third, a detailed examination of humorous sequences shows how these performative sequences can prove useful to maintain hierarchy. The results showed that there were few strategies aimed at challenging the status quo in this corpus, although they illustrate an ongoing movement towards a feminist humor that has been almost non-existent in Spain. (Orji, 2018) established a research that satire and humor, as enjoyed in all venues of stand-up comedy acts in Nigeria, are just a contemporary addition to what masks had done in the past but for dearth of proper documentation of these contributions. Using the resources of a combination of library and historical research, this paper investigated and re-establish historically the humor contributions of masking art in almost facets of human conditions.

In Indonesian context, some studies related to stand-up comedy have been conducted by some scholars. (Afidah, L, Wahyudi, 2014) analyzed Indonesian stand-up comedy performances by three comedians, Raditya Dika, Ryan Adryandhi, and Abel Achrian. Their study focused on the stand-up comedy's opening and ending part as the crucial part of the performance. Meanwhile, (Choiri, M.M, Ariyanti, 2014) investigated how illocutionary acts create humor on Reggy Hasibuan's stand-up comedy show. Their study showed that Reggy Hasibuan mostly used representative to make the hearers accept what his opinion is and he also used ridicule to create joke. (Fitri, 2013) wrote a paper of how the discourses of Chinese Indonesian are represented and (re)constructed through Ernest Prakasa's stand-up comedy in Indonesia, especially in Ernest's show 'Ernest Prakasa and The Oriental Bandits'. The paper examined the inter-textual and inter-discursive relationship between texts (Ernest's show transcript). The result of the paper showed 
that these strategies are used by Ernest for what called 'Chinese Wish' and as satire discourse for indigene. (Aris, 2019) examined stand-up comedy records staged in 2016 by the stand-up comedy local community in Kendari, Southeast Sulawesi and analyzed them based on the creation technique and the construction elements of stand humor discourse in terms of linguistic and non-linguistic context. The results showed that all the general concepts and theories of humor creation techniques are found. Those are (a) rhetoric, (b) tone variation, (c) irony, (4) language misunderstanding, (e) wordplay, (f) verbal jokes, (g) sarcasm, (h) satire, (i) sexual satire, and (i) deception. The study also confirmed that the most widely used were rhetoric, wordplay and deception.

Hence, considering no study discussed the sequence organization of jokes in Indonesian contexts, this paper tries to focus on the following questions:

a. What are the outlines of the narrative of the three finalists of Stand-Up Comedy Indonesia (SUCI) 5's texts?

b. Is there a difference between the three finalists of Stand-up Comedy Indonesia (SUCI) 5 in delivering their narratives?

The purpose of this study is to outline the three finalists of Stand-Up Comedy Indonesia (SUCI) 5 performances based on the sequential organization proposed by Scarpetta \& Spagnolli (2009) in order to find out whether Indonesian comics, represented by the finalists of SUCI 5 use the same pattern as same as foreign comics. Moreover, this study tries to reveal the differences among the Indonesian finalists of Stand-Up Comedy Indonesia (SUCI) 5 in term of delivering their stand-up comedy's materials. This study is expected to provide the new findings of how Indonesian comics present the structures of their narrative jokes, starting with the opening, establishing joke's topics, giving punch lines, then closing with delightful endings.

\section{RESEARCH METHODOLOGY}

This study applied Conversation Analysis (CA) as Atkinson, et al (1978) as cited in (Afidah, L, Wahyudi, 2014) explained that like conversation, stand-up is a "collaborative production" that is not only oriented to the stand-up comedian, but also to the people who are attending the show. Furthermore, Atkinson, et al (1978, p. 112) as cited in (Afidah, L, Wahyudi, 2014) also stated that as live interaction, stand-up and audience laugther, like talk in natural conversation, is "structured and ordered". Following the steps used by (Afidah, L, Wahyudi, 2014) that claimed the stand-up comedy is similar to natural conversation, this study used the Conversation Analysis to examine the data.

Schiffrin (1991, as cited in (Afidah, L, Wahyudi, 2014) stated that the term of Conversation Analysis has been used to describe work that is informed by a broad range of disciplinary perspectives including pragmatics, speech act theory, interactional sociolinguistics, ethno methodology, the ethnography of communication, variation analysis, communication theory and social psychology.

As Kompas TV holds a routine event namely Stand-Up Comedy Indonesia (SUCI) to facilitate Indonesian young people expressing their anxiety through humors, stand-up comedy gets more and more attention. SUCI has been held for seven seasons. SUCI offers people from the whole parts of Indonesia to join the audition that is held in several big cities in Indonesia. Through tight selections and assessments by some experience juries, fifteen participants are finally chosen to perform in SUCI shows weekly. By the end of the season, there are left three finalists of the best performance in grand final show. Using Youtube downloader software, the three videos of SUCI 5 grand final shows are downloaded from Stand Up Kompas TV Youtube site (http://www.youtube.com). The duration of each video is approximately five minutes. Then, the writers made the transcriptions of the videos, and then put the lines in a table.

The writers use (Scarpetta, F. \& Spagnolli, 2009)'s theory in analyzing the sequential organization of the three finalists of SUCI 5. This study focuses on the interactive context, whether they perform the following sequences:

i. Starting the interaction by begin their performance through interaction with the audience.

ii. Transition to a new joke sequence: a phase where the comics organize the movement from one joke sequence to the next.

iii. Expanding successful jokes: when the comics present a cascade of punch lines that rely on the premise of the first one.

iv. Referring to the audience in the punch line: when the comics exploit the audience as well as themselves as material of humor. 


\section{FINDINGS AND DISCUSSION}

Belows are the outlines of narrative from Indra, Rigen and Rahmet's performances, categorized by the sequential organization proposed by (Scarpetta, F. \& Spagnolli, 2009).

Table.1. Indra's outlines

\begin{tabular}{|c|c|}
\hline \multicolumn{2}{|c|}{ INDRA } \\
\hline Bits & Naration \\
\hline Step 1 & Selamat malam, Balai Kartini! (Acrobatic movement) \\
\hline Step 2 & Jujur gue gak nyangka bisa masuk ke grand final \\
\hline Step 4 & $\begin{array}{l}\text { Jangankan gue, grand final aja gak nyangka } \\
\text { kemasukan gue }\end{array}$ \\
\hline Step 2 & Rigen dan Rahmat ini gak pantes untuk jadi juara... \\
\hline Step 4 & ... dulu ya Rahmet itu sebenarnya Rigen \\
\hline Step 2 & Rahmet ini dari tampangnya gak ada juara-juaranya... \\
\hline Step 4 & Mukanya malah mirip Jayko, adiknya Giant \\
\hline Step 3 & Ini gigi apa pergi ke Dufan, jarang-jarang \\
\hline Step 2 & Rahmet ini suka bolos sekolah... \\
\hline Step 4 & Orang libur... \\
\hline Step 2 & $\begin{array}{l}\text { Rahmet ini buat yang belom tau ya umurnya baru } 19 \\
\text { tahun }\end{array}$ \\
\hline Step 4 & Gue pikir Rahmet itu tua, gak taunya kecil-kecil. \\
\hline Step 2 & $\begin{array}{l}\text { Rahmet dari awal pre-show kemaren dia selalu bahas } \\
\text { anak STM }\end{array}$ \\
\hline Step 4 & Gak ada materi STM nya, maksudnya \\
\hline Step 2 & Sekarang Rigen ... \\
\hline Step 4 & Gue mendingan mundur, mundur baru bisa \\
\hline Step 2 & Gue sering ke kosannya Rigen... \\
\hline Step 4 & Iya, orang tidurnya di kolam renang \\
\hline ii. Transition to a new joke sequence & Rigen ini anak terpaling tua... \\
\hline iv. Referring to the audience in the punch line & Adenya yang paling gede umurnya 5 hari \\
\hline ii. Transition to a new joke sequence & Rigen ini anak Vespa... \\
\hline iv. Referring to the audience in the punch line & $\begin{array}{l}\text { Ada juga yang stangnya ribet gitu, dari sini yang kanan } \\
\text { di sini, yang kiri di Madagaskar, jauh banget kan... }\end{array}$ \\
\hline Closing & Selamat malam, terima kasih. \\
\hline
\end{tabular}


Table.2. Rigen's outlines

\begin{tabular}{|c|c|}
\hline \multicolumn{2}{|c|}{ RIGEN } \\
\hline Bits & Naration \\
\hline Step 1 & $\begin{array}{l}\text { Assalamualaikum warahmatullahi wabarokatuh, } \\
\text { selamat malam Balai Kartini }\end{array}$ \\
\hline Step 2 & $\begin{array}{l}\text { Ya Rahmet ini, rahmet ini kita semua tahu ya, gue } \\
\text { seneng banget Rahmet sudah menceritakan banyak } \\
\text { mengenai STM... }\end{array}$ \\
\hline Step 4 & $\begin{array}{l}\text { Met, Lu bisa ngga ngitung kayak gitu? tawuran doang } \\
\text { lu tahunya }\end{array}$ \\
\hline Step 3 & Udah berapa orang yang mereka palak! \\
\hline Step 2 & $\begin{array}{l}\text { Rahmet hobbynya tuh ganti-ganti nama temen- } \\
\text { temennya... }\end{array}$ \\
\hline Step 4 & Itu si botak, SPG ama kontet. \\
\hline Step 3 & Rahmet!...Rahmet yang ngomong, bukan saya! \\
\hline Step 2 & $\begin{array}{l}\text { Udah gitu, Rahmet nih, kalo stand up comedy tuh lucu } \\
\text { banget }\end{array}$ \\
\hline Step 4 & $\begin{array}{l}\text { Selamat malam, gue Rahmeeet, suaranya pales (fals) } \\
\text { banget }\end{array}$ \\
\hline Step 3 & Selamat malam, gue Rahmeett, suara apa itu.. \\
\hline Step 2 & Indra kayaknya udah gak sabar ... \\
\hline Step 4 & $\begin{array}{l}\text { Lu ngalah kan? Soalnya mobil itu gue yang lebih } \\
\text { membutuhkan, dra! Elu udah ganteng. Cewek mah } \\
\text { gampang deket sama elu. Gue ini harus punya mobil, } \\
\text { ndra! }\end{array}$ \\
\hline Step 2 & Indra nih ya kalo misalkan ngomong tuh belibet. \\
\hline Step 4 & $\begin{array}{l}\text { Ndra elu kemaren ke Yogya gimana?...seru. Naik apa? } \\
\text {..Kereta. Nginep di mana?...hotel. }\end{array}$ \\
\hline Step 3 & $\begin{array}{l}\text { Tahu gitu mah ya gue juga nanya satu kata satu kata, } \\
\text { gitu. Yogya? Seru. Naik? Kereta. Nginap? Hotel. }\end{array}$ \\
\hline Step 2 & $\begin{array}{l}\text { Makanya mereka berdua nih gak ada yang cocok jadi } \\
\text { host SUCI. }\end{array}$ \\
\hline Step 4 & $\begin{array}{l}\text { Yang satu suaranya fals, yang satu ngomongnya } \\
\text { belibet. }\end{array}$ \\
\hline Step 3 & $\begin{array}{l}\text { Misalnya Indra jadi juara..disiarkan langsung dari balai } \\
\text { karapan sapi... }\end{array}$ \\
\hline Step 3 & $\begin{array}{l}\text { Giliran Rahmet, "Disiarkan langsung dari Balai Kartini } \\
\text { Jakartaa" (menirukan suara fals Rahmet) }\end{array}$ \\
\hline
\end{tabular}


Table.3. Rahmet's online

\begin{tabular}{|c|c|}
\hline \multicolumn{2}{|c|}{ RAHMET } \\
\hline Bits & Naration \\
\hline Step 1 & Assalamu'alaikum warahmatullahi wabarokatuh \\
\hline Step 2 & Wes, ....ada orang tua gue ngeliat gue pake jas \\
\hline Step 4 & Keren lu, Met, kayak caleg gagal! \\
\hline Step 3 & Katanye banyak yang bilang gue mirip babe ... \\
\hline Step 4 & Lu jangan girang, najis banget gue dimiripin sama elu! \\
\hline Step 2 & Gue kalo liat SUCI 5 ini, gue inget sama SUCI 3 ... \\
\hline Step 4 & $\begin{array}{l}\text { Ya belom tau lah! Belom diumumin! Sotoy lu semua! } \\
\text { Set dah! }\end{array}$ \\
\hline Step 2 & $\begin{array}{l}\text { Tapi kalo misalnya ini kompetisi pake sms, yah, gue } \\
\text { yakin gue yang juara... }\end{array}$ \\
\hline Step 3 & $\begin{array}{l}\text { Rigen...paling cuman Bima dan sekitarnya yang } \\
\text { ngirim SMS... }\end{array}$ \\
\hline Step 3 & Indra,... paling yang ngirim benda - benda mati... \\
\hline Step 4 & Gua yang ngirim SMS... anak STM seluruh Indonesia! \\
\hline Step 4 & Bukan sms dukungan, ngajak tawuran! \\
\hline Step 2 & $\begin{array}{l}\text { Tapi lima bulan gue nulis materi, hadiahnya puluhan } \\
\text { juta... }\end{array}$ \\
\hline Step 3 & $\begin{array}{l}\text { Orang kalo juara duitnya buat bayar utang orang tua } \\
\text { gua }\end{array}$ \\
\hline Step 4 & $\begin{array}{l}\text { Tapi sampein pesen ya, pinjem duit sama Rigen, sama } \\
\text { Indra }\end{array}$ \\
\hline Step 2 & Nih yang paling berambisi itu mah bokap gua... \\
\hline Step 4 & Hari ini puasa ya? Saya lupa. Untung lagi minum \\
\hline Step 3 & ..., coba lagi makan, gue disemprot rending \\
\hline Step 2 & $\begin{array}{l}\text { Udah gitu, gue certain dah tentang SUCI } 5 \text { itu kayak } \\
\text { gimana... }\end{array}$ \\
\hline Step 4 & $\begin{array}{l}\text { Kamu gak bakalan nge-blank, kamu kan gak nulis } \\
\text { materi, ya iyalah! }\end{array}$ \\
\hline Step 3 & Tapi gue waktu ke dukun tuh dikasih jampe-jampe ... \\
\hline Step 3 & Samiriko, domikopa, ndut-ndutan \\
\hline
\end{tabular}


From the findings, we can see that the three comics applied the whole serial stand-up performances suggested by (Scarpetta, F. \& Spagnolli, 2009). All participants start the interaction, and then do transition to a new joke sequence, after that they expand the successful jokes they have carried out that make audience burst into laughter, and finally they refer to the audience in the punch line.

\section{Starting the interaction}

(Scarpetta, F. \& Spagnolli, 2009) stated that the opening of an encounter is the start of the interaction, namely the place where mutual attention, availability, and willingness to engage in a specific kind of interaction are established. Furthermore, (Scarpetta, F. \& Spagnolli, 2009) explained that this section has examined the very beginning of each stand-up comedy performance, which is a time where the comedian and the audience can start working together at defining the interactional context in which all the subquent jokes will be located.

In session "Starting the interaction", the three finalists of SUCI 5 started the interaction by greeting the audience. "Selamat malam Balai Kartini". It is the universal greeting the three comics use in this grand final event. However, Indra did something different from the other comics. While greeting his audience, Indra did an acrobatic movement. This action stimulated his audience to hilariously interact with him. Rahmet and Rigen used Islamic greeting to open their performances, Assalamu'alaikum Warahmatullahi Wabarokatuh, while Indra used general greeting, Selamat malam (Goodnight).

\section{Transition to a new joke sequence}

This section is where the course of action and then the interactional business pursued is no longer the establishment of mutual attention. The comedian needs to organize the movement from one joke to the next (Scarpetta, F. \& Spagnolli, 2009) Two devices to achieve this transition are fillers and surveys. Fillers consist of chunks of talk with no meaning by themselves, but which postpone the delivery of a punch line (McIlvenny et al. (1993) as cited in (Scarpetta, F. \& Spagnolli, 2009), and surveys is constituted of some utterances that do not make laughter relevant, but rather set the condition for the upcoming punch line of the joke (Sacks, 1974, as cited in (Scarpetta, F. \& Spagnolli, 2009).

In session "Transition to a new joke sequence" it can be seen from the findings that the three participants applied this session. Indra is the one who used this session the most. He delivered more joke sequences compare to Rigen and Rahmet.

\section{Rahmet:}

"Wes, ....ada orang tua gue ngeliat gue pake jas" (Filler)

“Keren lu, Met, kayak Caleg gagal!” (Punch line)

Indra:

"Jujur gue gak nyangka bisa masuk ke Grand Final” (Filler)

"Jangankan gue, Grand Final aja gak nyangka kemasukan gue” (Punch line)

\section{Rigen:}

"Yah Rahmet ini, Rahmet ini kita semua tahu ya, gue seneng banget Rahmet sudah menceritakan banyak mengenai STM." (Surveys)

“Tawuran doang lu taunya!” (Punch line)

While Rigen started his first transition to a new joke sequence using surveys, Rahmet and Indra use filler to transit a new joke. Meanwhile Indra, started his first transition to a new joke by stated his feeling about being in the grand final, but with his specific linguistic skill in blowing audience mind in the next step.

\section{Expanding successful jokes}

(Scarpetta, F. \& Spagnolli, 2009) explained that once a punch line has been delivered, it is usually not dismissed immediately to start the preparation for a new joke sequence, but it is further exploited in a series of turns that expand the sequence and are responded to with laughter. In details, (Scarpetta, F. \& Spagnolli, 2009) stated that these expansions represent a cascade of punch lines that rely on the premises of the first one.

For session "Expanding successful jokes", Indra rarely expanded his jokes. It seems Rigen and Rahmet were more able to create funny and understandable humour. From the video that is completed by the writers with its transcripts, Indra tended to deliver new jokes rather than expanding the jokes. In this performance, he told his jokes shortly and then move to another jokes. This performance is different from Rigen, in term of Expanding successful jokes, Rigen took some chances by the time audience responded well his jokes for example when he stated that there are nickname that Rahmet has created for the jury of SUCI 5, as Rahmet likes to change his friends and 
teachers' name. Rigen expanded this part when he got great respons for his jokes about changing names that are responded well by the audience and the Juries. Rahmet delivered the area of sending SMS for Rigen, he delivered a sequence of receiving SMS for champion purpose, then expanded that Rigen just received SMS only from Bima, his hometown, while Rahmet received SMS from all people in Indonesia. This sequence got a good response from the audience, then Rahmet could see this good opportunity then he kept expanded this joke by talking about Indra's SMS poll.

\section{Referring to the audience in the punch line}

The study of (Scarpetta, F. \& Spagnolli, 2009) revealed that the comedian or the audience as the main material for the humor. They argued that using the comedian or the audience as a topic is not equivalent in terms of acceptability; obviously, making fun of the audience is more risky than making fun of the comedian. There are two options often altenated in the series of punch lines; selfreferred and audience-referred humour, and all punch lines are received with affiliative responses (Scarpetta, F. \& Spagnolli, 2009).
In session "Referring to the audience in the punch line", Rahmet used himself as the humour material, he commented his charming appearance when wearing suit then mentioned he was also like a failed legislative candidate. Rigen exploited the way Rahmet invited his friends to support him in SUCI 5, and invited audience to count the costs Rahmet's friends has spent to come to Balai Kartini, then Rigen worried that Rahmet's friends afforded by robbing people, a stereotype for STM students. Meanwhile Indra used a unique, words intelligent as his punch line. He played language to blow the meaning that made audience laugh. For example,"Jangankan gue, grand final aja ngga nyangka kemasukan gue." Or his statement," ... dulu ya Rahmet itu sebenarnya Rigen." The audience probably expected Indra was going to say that Rahmet itu sebenarnya ..something that related to his activity to practice his skill in doing stand-up comedy, then since his joke was out of the audience's expectation, he succeeded.

The findings above showed detail of the outline of narration from three finalist of SUCI 5. The analysis of the data findings described the layers of sequential steps used by the three finalists of SUCI 5. The comparison could be seen in the table below.

Table.4. Comparison of the three finalists

\begin{tabular}{|llll|}
\hline & Indra & Rigen & Rahmet \\
\hline Starting interaction & 1 & 1 & 1 \\
\hline Transition to a new joke sequence & 10 & 6 & 6 \\
\hline Expanding successful joke & 1 & 6 & 7 \\
\hline Referring to the audience in the punch line & 10 & 4 & 8 \\
\hline
\end{tabular}

Table. 4 shows the difference between the three finalists of SUCI 5, Indra, Rigen and Rahmet. We can infer that Indra mostly use the sequence of 'transition to a new joke - referring punch line'. Indra seems straight to jump from one joke to the next without trying to expand the previous successful joke. We can see Indra's the example as follow:

Rahmet ini buat yang belom tau ya umurnya baru 19 tahun, tapi kecil-kecil tua. (Transition to a new joke, using surveys) Iya, gue waktu pertama kali ngeliat Rahmet, gue pikir Rahmet itu tua, gak taunya kecil-kecil (Reffering the punch line).

Meanwhile, Rigen and Rahmet expand more the successful previous jokes. We can see from this extract:

Rigen:
"Makanya mereka berdua nih gak ada yang cocok jadi host SUCI. (Transition to a new joke, using filler) Yang satu suaranya flas, yang satu ngomongnya belibet. (Referring punch line). Misalnya Indra jadi juara. Disiarkan langsung dari balai karapan sapi..., giliran Rahmet,"Disiarkan langsung dari balai Kartini Jakartaaaa.. (Menirukan suara flas Rahmet)."(Expanding successful joke)

\section{Rahmet:}

"Tapi kalo misalnya ini kompetisi pake sms, yah, gue yakin gue yang juara. (Transition to a new joke, using filler). Rigen, paling cuman Bima dan sekitarnya yang ngirim sms. Indra, paling yang ngirim benda-benda mati. Gue yang ngirim sms, anak STM seluruh Indonesia! (Expanding successful joke). Bukan sms dukungan, ngajak tawuran! (Referring punch line. 
In term of punch line, the writers found that Indra creaeted more punch lines than the other two contestants. It could be inferred that Indra seems prefer to refer the punch lines than to expand the previous successful joke.

The previous studies presented in above are most merely cover the language style, discourse type, opening and ending part, and communicative techniques. Meanwhile, this paper tries to reveal layers and steps of each part, from the opening until the ending of each stand-up comedian. This paper describes more details of every sequential steps and the changing of each part, from starting interaction, transition to a new joke, expanding successful joke and referring the punch line.

\section{CONCLUSION}

The purposes of this study are first to find out the outlines of the narrative of the three finalists of SUCI 5's texts. Second is to analyze the differences among the three finalists of SUCI 5 in delivering their narratives. The object of this study are three finalists of grand final SUCI 5 that are achieved by downloading their performance from www.Youtube.com.

This study proves that the three finalists of SUCI 5 follow the sequential steps suggested by (Scarpetta, F. \& Spagnolli, 2009). Indra is the one who applied transition to a new joke sequence and referring to the audience in the punch line the most. In term of expanding successful joke, Rahmet applied this step the most. Three of them applied starting interaction step to begin their performance. The difference among the three finalists can be seen in terms of expanding successful joke, where Rahmet and Rigen tried to more expand their jokes rather than Indra.

This study aims to contribute research in sequential organization of Indonesian stand-up comedy. As this study merely focuses on sequential organization, there are more research area should be conducted in the future, such as explore the discourse type of Indonesian stand-up comedy or analyzed the interactional context of Indonesian stand-up comedy.

\section{REFERENCES}

Afidah, L, Wahyudi, R. (2014). How it starts and ends: A study of Indonesian stand-up comedy. Bahasa \& Sastra, 14(2), 170-189. https://ejournal.upi.edu/index.php/BS_JPBSP /article/view/716

Aris, B. (2019). Stand-up comedy humor discourse in local perspective in Indonesia. International Journal of Applied Linguistics and English Literature, 7(7), 222-238. https://www.journals.aiac.org.au/index.php/IJ ALEL/article/view/5055

Choiri, M.M, Ariyanti, L. (2014). Humor in Reggy Hasibuan's stand-up comedy show through illocutionary acts. Language Horizon, 2(3), $1-11$.

https://jurnalmahasiswa.unesa.ac.id/index.php /language-horizon/article/view/7452

Filani, I. (2015). Discourse types in stand-up comedy performances: An example of Nigerian stand-up cpmedy. Europian Journal of Humour Research, 3(1), 41-60. https://www.researchgate.net/publication/304 198385_Discourse_types_in_standup_comedy_performances_An_example_of_ Nigerian_stand-up_comedy

Fitri, F. . (2013). Discourse of Chinese-Indonesian in Ernest Prakasa's stand-up comedy Indonesia. Airlangga Unoversity.

Glick, D. . (2007). Some performative techniques of stand-up comedy: An exercise in the textuality of temporalization. Language \& Communication, 27, 291-306. https://www.researchgate.net/publication/229 178969_Some_performative_techniques_of_s tand-

up_comedy_An_exercise_in_the_textuality_o f_temporalization

Gurillo, L. R, Linares, E. (2019). Subversive humor in Spanish stand-up comedy. HUMORInternational Journal of Humor Research, 33(1), 29-54. http://griale.dfelg.ua.es/corpusfor-the-study-of-subversive-humor-inspanish-stand-up-comedy/

Hughes, B. . (2016). The psychology of stand-up comedy. Psychology Today. https://www.psychologytoday.com/us/blog/ho meostasis-disruptor/201606/the-psychologystand-comedy-0

Komedibadi. (2017). Yunani sebagai rahim komedi. http://www.comedibadi.id

Morris, A. L. (2011). Native American stand-up comedy: Epideictic strategies in the contact zone. Rhetoric Review, 30(1), 37-53. https://www.researchgate.net/publication/233 168344_Native_American_Stand- 
Up_Comedy_Epideictic_Strategies_in_the_C ontact_Zone

Orji, B. E. (2018). Humor, satire, and the emergent stand-up comedy: A diachronic appraisal of the contributions of making tradition. European Journal of Humor Research, 6(4), 24-28.

https://www.researchgate.net/publication/330 325316_Humour_satire_and_the_emergent_s tand-

up_comedy_A_diachronic_appraisal_of_the contributions_of_the_masking_tradition

Rullyanti, M, N. (2019). Language style of humor on stand-up comedy video. Journal of Applied Linguistics and Literature, 4(1), 6068.

https://www.researchgate.net/publication/332 837726_LANGUAGE_STYLE_OF_HUMO

\section{R_ON_STAND-UP_COMEDY_VIDEO}

Rutter, J. (2001). Rhetoric in stand-up comedy: Exploring performer-audience interaction. Stylistyka, $\quad X, \quad 307-325$. https://www.academia.edu/597798/Rhetoric_i n_Stand_up_Comedy_Exploring_Performer_ Audience_Interaction

Scarpetta, F. \& Spagnolli, A. (2009). The interactional context of humor in stand-up comedy. Research on Language and Social Interaction, 42(3), 210-230. https://www.researchgate.net/publication/233 436662_The_Interactional_Context_of_Hum or_in_Stand-Up_Comedy

Smith, D. R. (2018). The art of stand-up comedy. Comedy and Critique, 13-42. https://bristoluniversitypress.co.uk/comedyand-critique 